\title{
ISOLATION OF CANDIDA SPP FROM VAGINAL MICROBIOTA OF HEALTHY CANINE FEMALES DURING ESTROUS CYCLE
}

\author{
Marlete Brum Cleff ${ }^{1 *}$; Alzira Pacheco de Lima ${ }^{2}$; Renata Osório de Faria ${ }^{1}$; Ana Raquel Mano Meinerz \\ Tatiana de Ávila Antunes ${ }^{1}$; Flávia Biasoli de Araújo ${ }^{1}$; Patrícia da Silva Nascente ${ }^{3}$; Márcia de Oliveira Nobre²; \\ Mário Carlos Araújo Meireles ${ }^{1}$
}

\begin{abstract}
'Departamento de Veterinária Preventiva, Faculdade de Veterinária, Universidade Federal de Pelotas, Capão do Leão, RS, Brasil. ${ }^{2}$ Departamento de Clínicas Veterinária, Faculdade de Veterinária Universidade Federal de Pelotas, Capão do Leão, RS, Brasil. ${ }^{3}$ Programa de Pós-Graduação em Ciências Veterinária, Faculdade de Veterinária, Universidade Federal do Rio Grande do Sul, Porto Alegre, RS, Brasil
\end{abstract}

Submitted: November 03, 2004; Returned to authors for corrections: March 09, 2005; Approved: June 15, 2005

\begin{abstract}
Yeasts are commensal organisms found in the skin, genital and gastrointestinal tracts, and other mucosa in mammalians. Candida spp has been frequently isolated from domestic and sylvan animals. Yeast isolation from vaginal mucus is frequent in women, especially of Candida genus. In canine females, however, studies about vaginal fungal microbiota are rare and the connection with estrous cycle is unknown. The purpose of this study was to isolate yeast 5 of Candida genus from healthy canine females and identify the isolated species, establishing their connection with estrous cycle phases. Two hundred twenty-four samples taken from vaginal mucus of 14 canine females were analyzed in this study. Candida spp was observed in 83 (37\%) from these samples; nine samples were taken in proestrus, 14 in oestrus, 31 in dioestrus, 24 in anoestrus and five samples were obtained during pregnancy. Candida parapsilosis the most frequently isolated specie (21.7\%), followed by C. guillermondii (8.4\%), C. kefir (6\%) and C. albicans (4.8\%). We concluded that Candida spp is a commion component of healthy canine females' vaginal microbiota, and isolation varies according to the estrous cycle phase.
\end{abstract}

Key words: Candida spp, canine females, estrous cycle

\section{INTRODUCTION}

Yeasts of genus Candida are components of the microbiota of healthy beings and are described as causes of opportunistic mycoses around the world. These yeasts are widely distributed in the environment and frequently colonize skin and mucous membranes such as oral cavity and genital and gastrointestinal tracts of mammalians $(9,12,20,21,32)$. In dogs, yeasts belonging to Candida genus prefer constantly humid areas, which favor tissue maceration, as occurs in mucous membranes, mucocutaneous junctions, intertriginous areas, nail substructure inter-fingers areas, ear canal and lateral face of the ear $(20,33,36)$. Physiologic changes like estrous cycle and pregnancy are also considered predisposing factors for Candida spp proliferation $(6,10,38)$.

Hormonal changes that occur during estrous cycle in canine females cause morphological, clinical, cytological and vaginal modifications $(8,18,24,25)$. These changes may influence the development of microorganisms in the vaginal mucus (27). Studies establishing a relationship between the estrous cycle and the presence of Candida spp in vaginal microbiota of dogs are inexistent. The purpose of this study was three fold; to

*Corresponding Author. Mailing address: Universidade Federal de Pelotas, Faculdade de Veterinária, Departamento de Veterinária Preventiva, laboratório de Micologia, Campus Capão do Leão. 96010-900, Pelotas, RS, Brasil. E-mail: mbcleff@brturbo.com / meireles@ufpel.tche.br 
observe the presence of Candida genus yeasts in vaginal microbiota by healthy canine females; to identify the isolated species; and to verify their possible connection with estrous cycle phases.

\section{MATERIALS AND METHODS}

The presence of Candida genus yeasts on vaginal mucus of 14 healthy canine females was analyzed during ten months. The samples were collected in distinct estrous cycle phases. Estrous phases were determinated through examination of vaginal smears, together with physical and vaginal examination of the bitches $(8,25)$. Animals without true bred, from one to six years old, previously dewormed, were lodged in a research kennel. The dogs were fed with animal feed (Nhoc Supra, Alisul Alimentos S.A., Fábrica São Leopoldo, RS, Brasil) according to their body weight, and water was offered "ad libitum". Through the experimental period the animals did not receive any medicament.

Samples from each canine female were taken biweekly to determine estrous cycle phase and for yeast isolation. The samples $(n=217)$ were obtained with curettes and sterile swabs with the aid of a vaginal speculum. Two pregnant females of the experimental group were collected seven times during the pregnancy and at post-partum. Immediately after collection, the samples $(n=224)$ were streaked, on Sabouraud dextrose agar (Merck KgaA, 64271, Darmstadt, Germany) with chloranphenicol (Sanval Com. Ind. Ltda., São Paulo, SP, Brasil), and incubated at $37^{\circ} \mathrm{C}$ for up to seven days. The yeasts were characterized macromorphologically. The samples obtained from the swabs were submitted to Gram stain and to cytological examination for observation of vaginal epithelium cells morphology and determination of the estrous cycle phase.

Yeast colonies presenting macro and micromorphologic features of Candida genus were classified according to criteria and identifications tests preconized by Ahearn (2) for species determination.

The distribution of Candida spp frequencies in estrous cycle phases was analyzed using Fischercs test through Statistix 7.0 programm (Statistix 2000).

\section{RESULTS AND DISCUSSION}

Candida spp were isolated from 83 canine vaginal mucus samples representing $37 \%(\mathrm{n}=224)$ of the total samples. From 21 samples obtained during proestrus, nine (42.9\%) were positive; in oestrus from 32 samples, $14(43.8 \%)$ were positive. Fifty samples were obtained in dioestrus, and $31(62 \%)$ were positive. During anoestrus
Candida spp were isolated in $24(21.1 \%)$ out of 114 samples. Candida spp were isolated from five $(71.4 \%)$ out of seven samples collected from wo pregnant bitches (Table 1). The isolation of Candida spp was more frequent in dioestrus (62\%) than in anoestrus $(\mathrm{p}<0.0001)$. However, the difference between results obtained for proestrus and oestrus was not significant. Candida spp isolation in oestrus $(\mathrm{p}=0.0097)$ and proestrus $(\mathrm{p}=0.0326)$ was higher than in anoestrus (Table 1).

From Candida spp isolated fromthe 83 samples, only forty (48.2\%) were characterize to species level. We observed that C. parapsilosis was present in $18(21.7 \%)$ samples, $C$. guillermondii in seven (8.4\%), C. kefir in five (6\%), C. albicans in four (4.8\%), C. krusei in three (3.6\%) and C. glabrata in three (3.6\%).C. parapsilosis was isolated in all estrous cycle phases, with higher frequency in dioestrus followed by oestrus; other Candida species were more frequent in dioestrus and anoestrus. Candida spp isolation was lower in proestrus (Table 2).

In this work C. parapsilosis was the most frequent $(21.7 \%)$ among characterized species (Tab. 2). This species is considered of less pathogenic, but in the last years its importance in immunosupressed human patients has incilased $(5,9,16,26)$. In women, $C$. albicans is the species that most frequently causes vaginal candidiasis, followed by $C$. glabrata. $C$. tropicalis, $C$. kefir and $C$. krusei $(10,19,38)$. In this study the frequency of $C$. albicans was low (8\%), wich explains the absence of vaginitis caused by Candida in the studied bitches.

The incidence of Candida spp (37\%) (Table 1) in the vaginal cavity of healthy canine females was similar to that reposted in the same anatomic site for healthy women (20 to 48\%) $(1,23,31,38)$, while higher frequencies were mentioned in vaginitis cases $(6,10,38)$. Despite isolation of Candida from sites like ear canal $(3,7)$, skin $(14,30)$ and nasal, oral and anal mucus of canine females (13), the literature does not mention vaginitis caused by Candida cited in bitches, nor presence of Candida in the vaginal mucus of healthy animals.
Table 1. Candida spp isolation from 224 vaginal cavity samples from 14 canine females in distinct estrous cycle phases* (Researchskennel from Veterinary Hospital, Federal University of Pelotas, RS, 2003).

\begin{tabular}{lcccccc}
\hline & \multicolumn{7}{c}{ Estrous Cycle Phases } & & \\
\cline { 2 - 6 } Candida spp & $\begin{array}{c}\text { Proestrus } \\
\mathrm{n}(\%)\end{array}$ & $\begin{array}{c}\text { Oestrus } \\
\mathrm{n}(\%)\end{array}$ & $\begin{array}{c}\text { Dioestrus } \\
\mathrm{n}(\%)\end{array}$ & $\begin{array}{c}\text { Anoestrus } \\
\mathrm{n}(\%)\end{array}$ & $\begin{array}{c}\text { Pregnancy } \\
\mathrm{n}(\%)\end{array}$ & $\begin{array}{c}\text { Total } \\
\mathrm{n}(\%)\end{array}$ \\
\hline Positive & $9(42.9)^{\mathrm{ac}}$ & $14(43.8)^{\mathrm{ac}}$ & $31(62)^{\mathrm{a}}$ & $24(21.1)^{\mathrm{b}}$ & $5(71.4)$ & $83(37)$ \\
Negative & $12(57.1)$ & $18(56.2)$ & $19(38)$ & $90(78.9)$ & $2(28.6)$ & $141(63)$ \\
\hline Total & $21(100)$ & $32(100)$ & $50(100)$ & $114(100)$ & $7(100)$ & $224(100)$ \\
\hline
\end{tabular}

$\mathrm{n}=$ absolute number; $(\%)=$ percentage; ${ }^{*} \mathrm{p}<0.05 ;{ }^{\mathrm{a}, \mathrm{b}, \mathrm{c}}$ different exponents at the same line vary on minimum $\mathrm{p}<0.05$. 
Table 2. Frequency of Candida yeast species on samples of canine females vaginal cavity in different estrous cycle phases* (Researchskennel from Veterinary Hospital, Federal University of Pelotas, RS, 2003).

\begin{tabular}{|c|c|c|c|c|c|c|}
\hline \multirow[b]{2}{*}{ Candida spp } & \multicolumn{4}{|c|}{ Estrous Cycle Phases } & \multirow[b]{2}{*}{$\begin{array}{c}\text { Pregnancy } \\
\mathrm{n}(\%)\end{array}$} & \multirow[b]{2}{*}{$\begin{array}{l}\text { Total } \\
\mathrm{n}(\%)\end{array}$} \\
\hline & $\begin{array}{c}\text { Proestrus } \\
\mathrm{n}(\%)\end{array}$ & $\begin{array}{c}\text { Oestrus } \\
\mathrm{n}(\%)\end{array}$ & $\begin{array}{c}\text { Dioestrus } \\
\mathrm{n}(\%)\end{array}$ & $\begin{array}{c}\text { Anoestrus } \\
\mathrm{n}(\%)\end{array}$ & & \\
\hline Candida al & $u s \quad-$ & - & $2(6.5)$ & $1(4.1)$ & $1(20)$ & $4(4.8)$ \\
\hline C. glabrata & - & - & $2(6.5)$ & $1(4.2)$ & - & $3(3.6)$ \\
\hline C. guillermondii & - & $1(7.1)$ & $3(9.7)$ & $2(8.3)$ & $1(20)$ & $7(8.4)$ \\
\hline C. krusei & $1(4.8)$ & - & $1(3.2)$ & $1(4.2)$ & - & $3(3.6)$ \\
\hline C. parapsilosis & $1(11.1)$ & $3(21.4)$ & $7(22.6)$ & $4(8.3)$ & $3(60)$ & $18(21.7)$ \\
\hline C. kefir & - & 1 & $2(6.5)$ & $2(8.3)$ & - & $5(6)$ \\
\hline Candida spp & $7(33.3)$ & $9(64.3)$ & $14(45.1)$ & $13(54.2)$ & - & $43(51.8)$ \\
\hline Total & $9(100)$ & $14(100)$ & $31(100)$ & $24(100)$ & $5(100)$ & $83(100)$ \\
\hline
\end{tabular}

phase (37). Basal hormones concentration $(4,8,35)$, and alkaline vaginal $\mathrm{pH}$ are adverse conditions to fungi development (27) and could, probably, account for little Candida spp isolation in anoestrus.

Yeast positive vaginal cavity samples obtained from two pregnant bitches are, possibly, associated with immune suppression that occurs in the female reproductive tract at the time of implantation and throughout pregnancy (37). However, the low number of pregnant animals in this study does not allow us to conclude that yeasts are normally present in vaginal cavity in pregnant bitches. In spite of differences on reproductive cycles, the frequencies obtained for Candida genus yeasts in pregnant canine females $(71.4 \%)$ were similar to those of pregnant women $(68 \%)(1)$.

\section{CONCLUSIONS}

The high incidence of Candida spp during dioestrus (62 $\%$ ) may be linked to high progesterone levels in this phase (17) Candida-specific cell-mediated immunity, acquired by exposure to Candida as a commensal early in life, has been considered the predominant host defense mechanism against mucosal Candida infections (11), acting as cellular immunity suppressor, and promoting the expression of a gene that favours synthesis of an epithelial receptor able to bind certain fungi (38). Studies suggest that estrogen, but not progesterone, is important in the reproductive-hormone-associated susceptibility to vaginal $C$. albicans infection $(10,11)$. The high estrogen levels in proestrus $(18,28,35)$ can account for Candida isolation in this phase. Fungi development is enhanced by this hormone which increases glycoproteic epithelial complexes exposition acting as receptors for fungi agents (38). Estrogen or also stimulate glycogen collection (15), and the decrease of the vaginal $\mathrm{pH}$ due to its metabolization to lactic acid supports to lactobacillus and yeasts growth $(22,27)$. Immunoglobulin $\mathrm{A}(\operatorname{Ig} \mathrm{A})$ and $\mathrm{IgG}$ are the predominant Ig classes found in vaginal washes, suggesting that they represent the dominant Igs in the female genital tract (29). Decrease of these immunoglobulines in proestrus due to high estrogen levels is also considered as a factor that could influence yeast growth (37). Sex steroid hormones regulate the movement of mucosal IgA antibody and its transporter, polymeric immunoglobulin receptor, from uterine tissues into secretions (34). Biological models demonstrated that estrogen and progesterone levels are high in oestrus, increasing uterine and reducing vaginal immune function, what could justify Candida spp isolation in this
Our results indicate that Candida spp yeasts are component parts of vaginal microbiota of healthy canine females. The isolation frequency was higher in dioestrus and lower in anoestrus. The isolated species were: $C$. parapsilosis, $C$. guillermondii, C. kefir, C. albicans, C. glabrata and C. krusei, with $C$. parapsilosis being the most frequent. The species isolated in pregnant bitches were $C$. albicans, $C$. guillermondii and $C$. parapsilosis.

\section{ACKNOWLEDGEMENTS}

This study was supported by the Fundação Coordenação de Aperfeiçoamento de Pessoal de Nível Superior (CAPES), Conselho Nacional de Desenvolvimento Científico e Tecnológico (CNPq), Fundação de Apoio à Pesquisa do Rio Grande do Sul (FAPERGS) and Progama de Pós-Graduação em Veterinária da Universidade Federal de Pelotas - UFPel.

\section{RESUMO}

\section{Isolamento de Candida spp da microbiota vaginal de fêmeas caninas hígidas durante o ciclo estral}

As leveduras são organismos comensais da pele, trato genital e gastrointestinal, e de outras mucosas de mamíferos. O gênero Candida vem sendo isolado freqüentemente de animais domésticos e silvestres. O isolamento de Candida spp da mucosa vaginal de mulheres é freqüente, porém na espécie canina são 
escassos os estudos referentes à microbiota fúngica vaginal, especialmente do gênero candida, não se tendo conhecimento de sua relação com o ciclo reprodutivo. O presente trabalho teve como objetivo isolar leveduras do gênero Candida em fêmeas caninas hígidas e identificar as espécies isoladas, relacionando-as com as diferentes fases do ciclo estral. Foram analisadas 224 amostras obtidas da mucosa vaginal de 14 fêmeas caninas. Candida spp foi observada em 83 (37\%) amostras, destas, nove $(42,9 \%)$ foram obtidas no proestro, $14(43,8 \%)$ no estro, $31(62 \%)$ no diestro, $24(21,1 \%)$ no anestro e cinco $(71,4 \%)$ de gestantes. Nas amostras caracterizadas, $C$. parapsilosis foi a espécie isolada com maior freqüência $(21,7 \%)$, seguida de $C$. guillermondii (8,4\%), C. kefir (6\%) e C. albicans (4,8\%). Com base neste estudo pode-se concluir que Candida spp faz parte da microbiota vaginal de fêmeas caninas hígidas, e que o isolamento é influenciado pelo ciclo reprodutivo.

Palavras-chave: Candida spp, fêmeas caninas, ciclo estral

\section{REFERENCES}

1. Abu-Elteen, K.H.; Malek, N.; Amma Wahid, N.A.A. Prevalence and susceptibility of vaginal yeast isolates in Jordan. Mycoses., 40, 179$185,1997$.

2. Ahearn, D.G. Identification and ecology of yeasts of medical importance. In: Opportunistic Pathogens. University Park Press, Baltimore, 1974, p.129-146.

3. Bornand, V. Bactériologie et mycologie de l'otite externe du chien. Schweiz. Arch. Tierheilk., 134, 1-8, 1992.

4. Concannon, P.W.; McCann, J.P.; Temple, M. Biology and endocrinology of ovulation, pregnancy and parturition in the dog. $J$. Reprod. Fert., (supplemment). 39, 3-25, 1989.

5. Dick, J.D. Fatal disseminat candidiasis due to amphotericin-B resistant C. guillermondii. Amer. Intern. Med., 102, 67-68, 1985.

6. Fahey, J.V.; Wira, C.R. Effect of menstrual status on antibacterial activity and secretory leukocyte protease inhibitor production by human uterine epithelial cells in culture. The J. Infect. Dis., 185, 1606-1613, 2002.

7. Feijó, F.M.C.; Campos, S.G.; Ramadinha, R.H.R. Características de Candida tropicalis como patógeno em otites. XXV Congresso Brasileiro de Medicina Veterinária, Gramado, 1997, p. 150.

8. Feldman, E.C.; Nelson, R.W. Ovarian cycle and vaginal cytology. In: Feldman, E.C.; Nelson, R.W. Canine and Feline Endocrinology and Reproduction, 2. ed., Saunders, Philadelphia, 1996, p. 529-546.

9. Ferreira, A.W.; Avila, S.L.M. Diagnóstico laboratorial das principais doenças infecciosas e autoimunes. Guanabara Koogan, Rio de Janeiro, 1996. 302 p.

10. Fidel, J.R.; Cutright, J.; Steele, C. Effects of reproductive hormones on experimental vaginal candidiasis. Infect. Immun., 68, 2, 2000.

11. Fidel Jr., P.L. Immunity in vaginal candidiasis. Cur. opin. Infect. Dis., 18, 107-111, 2005.

12. Fotos, P.G.; Hellstein, J.W. Candida and candidosis: epidemiology, diagnosis and therapeutic management. Dent. Clin. North Amer., 36(4), 857-878, 1992.

13. Greene, C.E.; Chandler, F.W. Candidiasis. In: Infectious diseases of dog and cat. Saunders, Philadelphia, $2^{\text {th }}$ ed., 1998. p. 414-417.

14. Guillot, J.; Chermette, R.; Gueho, E. Prevalence du genre Malassezia chez les mammiferes. J. Mycol. Med., 4, 72-79, 1994.

15. Hafez, E.S.E. Reprodução Animal. $6^{\text {th }}$ ed., Manole, São Paulo, 1995. $582 \mathrm{p}$.
16. Hahn, R.C; Resende, J.C.P.; Primola, N.S.; Moraes, E.M.P.; Hamdan, J.S. Vulvovaginite recorrente por Candida parapsilosis: Problema emergente? XX Congresso Brasileiro de Microbiologia, Salvador, 1997, p. 86.

17. Jeffcoate, I. Physiology and Endocrinology of the bitch. In: BSVA Manual of small animal reproduction and neonatology. British Small Animal Veterinary Association, 1998. p. 1-9.

18. Jöchle, W.; Andersen, A. C. The estrous cycle in the dog: a review. Theriogenology, 7(3), 113-140, 1977.

19. Kano, R.; Hattori, Y.; Okuzumi, K.; Miyazaki, Y.; Yamauchi, R.; Koie, H.; Watari, T.; Hasegawa, A. Detection and identification of Candida species by $25 \mathrm{~S}$ ribossomal DNA analysis in the urine candidal cystitis. J. Vet. Med. Sci., 64(2), 115-117, 2001.

20. Know-Chung, K.J.; Benett, J.E. Medical mycology. Lea \& Febiger, Philadelphia, 1992.

21. Lacaz, C.S.; Pettinati, A.S.; Salebian, A. Candidíases. Ed. Universidade de São Paulo, São Paulo, 1980. 190 p.

22. Lacaz, C.S; Porto, E.; Heins-Vaccari, E.M.; Melo, N.T. Guia para identificação: fungos, actinomicetos e algas de interesse médico. Sarvier, São Paulo, 1998, 445 p.

23. Linares, L.M.; Marin, C. Frequency of yeasts of the genus Candida in humans as pathogens and as part of normal flora. Proceedings of the IV International Conference on the Mycoses. Pan American Health Organization, Washington, 356, 1978, p.124.

24. Linde, C.; Karlsson, I. The correlation between the cytology of the vaginal smear and the time of ovulation in the bitch. J. Small An. Pract., 25, 77-82, 1984.

25. Mialot, J.P. Patologia da reprodução dos carnívoros domésticos. A H. Vet., 1988, 160p.

26. Odds, F.C. Ecology and epidemiology of candidiasis. In: Candida and Candidosis. Leicester University Press, Baltimore, 1988. p. 89.

27. Oliveira, C.M.; Costa, E.O.; Silva, J.A.P. Microbiota aeróbica em fêmeas caninas hígidas durante o ciclo estral. Avaliação da sensibilidade aos antimicrobianos. Rev. Bras. Med. Vet., 20(2), 78-84, 1998.

28. Olson, P.N.; Nett, T.M. Reproductive endocrinology and physiology of the bitch. In: Morrow, D. A. Current therapy in theriogenology. Saunders, Philadelphia, 1986, p.453-457.

29. Parr, M.B.; Parr, E.L. Mucosal immunity in the female and male reproductive tracts. In: Ogra, P.L.; Mestecki, J.J.; Lamm M.E.(ed.) Handbook of mucosal immunity. Academic Press, San Diego, 1994, p.677-689.

30. Raposo, J.B.; Nobre, M..O.; Fernandes, C.G.; Porto, M. Candidíase cutânea em um canino. Rev. Fac. Zoot. Vet. Agron., Uruguaiana, 2/3 (1), 11-14, 1996.

31. Ribeiro, M.A.; Dietze, R.; Paula, C.R.; Matta, D.A.; Colombo, A.L. Susceptibility profile of vaginal yeast isolates from Brazil. Mycopathologia, 151(1), 5-10, 2001.

32. Rippon, J.N. The pathogenic fungi and the pathogenic actinomycetes. In: Rippon, J.N. Medical Mycology. Saunders, Philadelphia, 1988. $797 \mathrm{p}$.

33. Sidrim, J.J.C.; Moreira, J.L.B. Fundamentos clínicos e laboratoriais da micologia médica. Guanabara Koogan, Rio de Janeiro, 1999. 287p.

34. Sullivan, D.A.; Richardson, G.S.; MacLaughlin, D.T.; Wira, C.R. Variations in the levels of secretory component in human uterine fluid during the menstrual cycle. J. Steroid. Biochem., 20, 509-513, 1984.

35. Valtonen, M.; Jalkanen, L. Species-specific features of oestrus development and blastogenesis in domestic canine species. J. Reprod. Fertil., (supplemment). 47, 133-137, 1993.

36. Willemse, T. Dermatologia clínica de cães e gatos: guia para diagnóstico e terapia. Manole, São Paulo, 1995. 141p.

37. Wira, C.R.; Rossoll, R.M.; Kaushic, C. Antigen-presenting cells in the female reproductive tract: Influence of estradiol on antigen presentation by vaginal cells. Endocrinology, 141, 2877-2885, 2000.

38. Ziarrusta, G.B. Vulvovaginitis candidíasica. Rev. Iberoam. Mec., 19, $22-24,2002$. 